\title{
Audit Tata laksana Meningitis Bakterialis pada Anak di RSUP Dr. Sardjito
}

\author{
I Putu Ardika Yuda, Sunartini, Neti Nurani \\ Bagian Ilmu Kesehatan Anak Fakultas Kedokteran Universitas Gadjah Mada/ RSUP Dr. Sardjito, \\ Yogyakarta
}

Latar belakang. Angka kematian dan disabilitas pasien meningitis bakterialis masih cukup tinggi serta berhubungan dengan kualitas pelayanan. Audit medis perlu dilakukan sebagai salah satu upaya meningkatkan patient safety.

Tujuan. Mengetahui kesesuaian antara praktik tata laksana meningitis bakterialis pada anak yang dirawat di bangsal anak RSUP Dr. Sardjito dengan pedoman pelayanan medis berdasarkan standar pelayanan medis (SPM) RSUP Dr. Sardjito 2005 dan (Pedoman Pelayanan Medis) PPM IDAI 2010.

Metode. Audit retrospektif dengan menggunakan pedoman audit berdasarkan SPM RSUP Dr. Sardjito tahun 2005 dan PPM IDAI tahun 2010. Subjek penelitian adalah anak usia 1 bulan-18 tahun dengan diagnosis meningitis bakterialis yang dirawat di bangsal anak RSUP Dr. Sardjito pada 1 Januari 2011 sampai dengan 31 Mei 2013.

Hasil. Terdapat 114 anak dengan diagnosis meningitis bakterialis. Rata-rata lama waktu penanganan di UGD adalah 89 menit dengan median 78 menit. Median lama waktu dilakukannya pungsi lumbal sejak pasien masuk adalah 4,5 jam (rata-rata 13,9 jam, rentang interkuartil 2,3-18,2 jam). Enampuluh dua pasien (54,4\%; 95\%CI: 49,7-59, 1\%) yang mendapatkan antibiotik dosis intrakranial dalam waktu 6 jam sejak pasien masuk. Namun, defisiensi ini tidak terbukti memengaruhi outcome kematian (OR: 0,7; 95\%CI: 0,18-3,0; $\mathrm{p}=0,480$ ) maupun terjadinya sekuel (OR: 1,1; 95\%CI: 0,4-2,5; p=0,839). Pemeriksaan uji fungsi pendengaran dengan Brainstem Evoked Respons Audiometri (BERA) hanya dilakukan pada 26/63 (41,3\%; 95\%CI: 29,1-53,5\%) pasien.

Kesimpulan. Belum semua kasus tata laksana meningitis bakterialis memenuhi standar mutu sesuai pedoman. Perlu diadakan pelatihan atau workshop tata laksana meningitis bakterialis pada anak di RSUP Dr. Sardjito. Sari Pediatri 2014;16(2):115-20.

Kata kunci: meningitis bakterialis, audit medis, patient safety

Alamat korespondensi:

Dr. I Putu Ardika Yuda, Sp.A. Bagian Ilmu kesehatan Anak FK UGM/ RSUP Dr. Sardjito. Jl. Kesehatan no.1 Yogyakarta. Hp: 081348343801.

E-mail:farmadika@yahoo.com

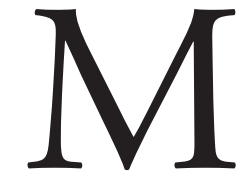
eningitis bakterialis membutuhkan pengenalan dan penanganan segera untuk mencegah kematian dan disabilitas. Sampai saat ini, terutama di negara berkembang, meningitis bakterialis merupakan 
infeksi pada anak yang menakutkan, menyebabkan mortalitas dan morbiditas yang tinggi. Angka mortalitas dapat mencapai 5\%-10\% dan sekuel dapat terjadi pada $50 \%$ anak yang terkena. ${ }^{1,2}$ Di samping akibat perjalanan penyakitnya, kematian pada meningitis juga dapat diakibatkan oleh penanganan yang tidak adekuat, di antaranya keterlambatan pengenalan tanda dan gejala atau diagnosis, keterlambatan pemberian antibiotik, dan ketidaktepatan dosis antibiotik. ${ }^{3}$

Audit medis adalah upaya evaluasi secara profesional terhadap mutu pelayanan medis yang diberikan kepada pasien dengan menggunakan rekam medis yang dilaksanakan oleh profesi medis. ${ }^{4}$ Di Inggris, audit medis sudah menjadi bagian penting dalam pelayanan kesehatan dan setiap dokter dalam 2 tahun pertama diwajibkan untuk melakukan audit medis di berbagai rumah sakit. ${ }^{5}$

Di RSUP Dr. Sardjito, audit tata laksana meningitis bakterialis pada anak pernah dilakukan tahun 1996 dengan sampel anak yang dirawat inap dengan diagnosis meningitis periode 1 Januari 1990 sampai dengan 31 Desember 1994. Saat itu, tata laksana meningitis menggunakan protokol tata laksana meningitis pada anak tahun 1989, tetapi hasil penelitian tersebut hanya dipublikasikan di KONIKA tahun 1996 di Bukit Tinggi. Seiring dengan perkembangan penemuan baru di bidang tata laksana meningitis bakterialis pada anak, di antaranya perubahan penggunaan antibiotik dan deksametason iv dan telah diterbitkannya pedoman pelayanan medis oleh Ikatan Dokter Indonesia tahun 2010 maka audit medis ini perlu kembali dilakukan. Disamping itu, angka kematian dan disabilitas akibat meningitis yang masih tinggi saat ini menunjukkan bahwa audit ini harus dilakukan kembali.

Tujuan audit ini adalah untuk mengetahui kesesuaian antara praktek tata laksana meningitis bakterialis pada anak yang dirawat di bangsal anak RSUP Dr. Sardjito dengan pedoman pelayanan medis untuk meningitis bakterial berdasarkan SPM RSUP Dr. Sardjito 2005 dan PPM IDAI 2010.

\section{Metode}

Jenis penelitian ini adalah audit retrospektif dengan menggunakan pedoman audit berdasarkan SPM RSUP Dr. Sardjito tahun 2005 dan PPM IDAI tahun 2010. Pedoman audit memuat kriteria dan standar yang harus terpenuhi dan telah disepakati oleh tim audit berdasarkan rapat penetapan pedoman audit tanggal 4 Juli 2013. Subjek penelitian adalah anak usia 1 bulan-18 tahun dengan diagnosis meningitis bakterialis yang dirawat di bangsal anak RSUP Dr. Sardjito pada 1 Januari 2011-31 Mei 2013. Data tata laksana meningitis bakterialis diperoleh dari rekam medis dan dibandingkan dengan kriteria dan standar. Dikatakan deviasi jika kriteria yang dinilai tidak memenuhi unsur atau kriteria dan tidak memenuhi kriteria pengecualian. Dinyatakan defisiensi jika tidak terdapat penjelasan yang beralasan terhadap tidak terpenuhi unsur dan perkecualian pada setiap kriteria yang dinyatakan deviasi. Analisis penyebab deviasi dan defisiensi dilakukan untuk mencari kemungkinan penyebab dan untuk perumusan saran atau rekomendasi.

\section{Hasil}

Terdapat 114 anak dengan diagnosis meningitis bakterialis (Tabel 1). Seratus tiga $(90,4 \%)$ pasien masuk melalui UGD, 1 pasien merupakan pasien alih rawat dari bangsal bedah anak pasca operasi hernia inguinalis setelah dirawat selama 3 hari. Rata-rata lama waktu penanganan di UGD adalah 89 menit dengan median 78 menit. Berdasarkan ketentuan di RSUP Dr. Sarjito, lama penanganan di UGD tidak boleh lebih

Tabel 1. Karakteristik pasien

\begin{tabular}{lc}
\hline Karakteristik & $\mathrm{n}(\%)$ \\
\hline Usia & \\
$1-12$ bulan & $64(56,1)$ \\
12 bulan -5 tahun & $31(27,2)$ \\
5 tahun -18 tahun & $19(16,7)$ \\
Jenis kelamin & \\
Laki laki & $71(62,3)$ \\
$\quad$ Perempuan & $43(37,7)$ \\
Pasien rujukan & $91(79,8)$ \\
Cara masuk & \\
UGD & $103(90,4)$ \\
Poliklinik anak & $10(8,8)$ \\
Alih rawat dari bangsal lain & $1(0,8)$ \\
Lama penanganan di UGD (jam) & \\
0-2 & $80(70,2)$ \\
$>2$ & $24(21,1)$ \\
Tidak ada data & $10(8,8)$ \\
Rata-rata & $89 \pm 53,6$ menit \\
\hline
\end{tabular}


dari 120 menit/pasien. Dengan demikian, berdasarkan ketentuan tersebut $24(21,1 \%)$ kasus tidak memenuhi ketentuan. Tidak terdapat alasan pada catatan medis mengenai penanganan pasien di UGD yang lebih dari 120 menit.

Pemeriksaan dan pemantauan tingkat kesadaran dengan Pediatric Glasgow Coma Scale (PCS) dan tekanan darah masih jarang dilakukan di UGD. Skor PCS tertulis 52 kasus (45,6\%; 95\%CI: 36,5-54,7\%) dan tekanan darah 19 kasus (16,7\%; 95\%CI: 9,9-23,5\%). Pungsi lumbal untuk pemeriksaan cairan serebrospinal
Hanya 62/114 pasien (54,4\% 95\%CI: 49,7$59,1 \%$ ) yang mendapatkan antibiotik dosis intrakranial dalam waktu 6 jam sejak pasien masuk. Tidak ditemukan perbedaan angka kematian pada pasien yang mendapatkan antibiotik kurang dari 6 jam dibandingkan dengan pasien yang mendapatkan antibiotik lebih dari 6 jam, $\mathrm{p}=0,480(\mathrm{p}>0,05)$. Dibandingkan dengan pasien dengan kondisi umum baik saat datang, antibiotik lebih cepat diberikan pada pasien dengan kondisi umum buruk, rata-rata 3,5 \pm 2,2 jam dengan nilai $\mathrm{p}=0,000(\mathrm{p}>0,05)$.

Tabel 2. Kriteria audit dan luaran

\begin{tabular}{|c|c|c|c|}
\hline Kriteria & Standar $(\%)$ & Terpenuhi n/N (\%) & $95 \% \mathrm{CI}$ \\
\hline Pemeriksaan kesadaran dan pemantauan kesadaran dengan skor PCS & 100 & $52 / 114(45,6)$ & $36,5-54,7$ \\
\hline Pemantauan vital sign mencakup nadi, suhu,, dan tekanan darah & 100 & $19 / 114(16,7)$ & $9,9-23,5$ \\
\hline $\begin{array}{l}\text { Lumbal pungsi dilakukan pada anak yang dicurigai meningitis } \\
\text { bakterialis }\end{array}$ & 100 & $90 / 114(78,9$ & $71,4-86,4$ \\
\hline Pengecatan gram dilakukan pada semua sampel CSS & 100 & $47 / 90(52,2)$ & $43,1-52,5$ \\
\hline $\begin{array}{l}\text { Pemeriksaan uji fungsi pendengaran (BERA) dilakukan segera setelah } \\
\text { pasien dipulangkan }\end{array}$ & 100 & $26 / 63(41,3)$ & $29,1-53,5$ \\
\hline
\end{tabular}

Tabel 3. Alasan tidak dilakukannya pungsi lumbal $(\mathrm{n}=24)$

\begin{tabular}{ll}
\hline Alasan & $\mathrm{n}(\%)$ \\
\hline Pungsi lumbal gagal & $4(16,7)$ \\
Terdapat kontraindikasi pungsi lumbal & \\
$\quad$ Syok/gangguan hemodinamik & $4(16,7)$ \\
$\quad$ Curiga ada proses desak ruang (herniasi) & $1(4,2)$ \\
Penolakan orangtua atau keluarga & \\
$\quad$ Karena takut komplikasi & $3(12,5)$ \\
$\quad$ Tidak dijelaskan alasan penolakan spesifik & $10(41,6)$ \\
Pungsi lumbal dan analisis cairan CSS sudah dilakukan di RS sebelumnya & $1(4,2)$ \\
Diagnosis kecurigaan meningitis bakterialis terlambat ditegakkan & $1(4,2)$ \\
\hline
\end{tabular}

(CSS) dilakukan pada 90 pasien (78,9\%; 95\%CI: 71,4$86,4 \%)$. Pengecatan gram untuk identifikasi bakteri patogen dilakukan pada 47/90 (52,2\%; 95\%CI: 43,1$52,5 \%)$. Tes pendengaran dengan BERA dilakukan pada 26/63 (41,3\%; 95\%CI: 29,1-53,5\%) pasien yang hidup, 1 pasien menolak pemeriksaan BERA karena faktor biaya, dan $37(58,7 \%)$ tidak ada penjelasan mengenai tidak dilakukannya pemeriksaan BERA.

Terdapat 13/114 (11,5\%) penolakan terhadap tindakan pungsi lumbal oleh orangtua (Tabel 3). Sebagian besar tidak menuliskan alasan penolakan di formulir penolakan tindakan medis. Tiga orang menyatakan takut komplikasi akibat tindakan pungsi lumbal.

\section{Pembahasan}

Pemeriksaan dan pemantauan tingkat kesadaran dengan Pediatric Glasgow Coma Scale (PCS) dan tekanan darah masih jarang dilakukan di UGD. Penilaian tingkat kesadaran sebaiknya dilakukan dengan skor PCS karena merupakan parameter yang objektif, terukur, dapat divalidasi, dan telah disepakati secara umum oleh klinisi sehingga dapat digunakan untuk memantau perkembangan kesadaran pasien secara objektif. ${ }^{6,9}$ Selain itu, penurunan skor PCS $>3$ poin menunjukkan telah terjadinya peningkatan tekanan intrakranial yang berarti. ${ }^{6}$ Sama halnya dengan tekanan darah, tekanan darah harus diukur dan dipantau pada 
Tabel 4. Analisis bivariat prediktor yang memengaruhi kematian

\begin{tabular}{|c|c|c|c|c|}
\hline Prediktor & Meninggal n (\%) & Hidup n (\%) & $\mathrm{p}$ & OR $(95 \% \mathrm{CI})$ \\
\hline \multicolumn{5}{|l|}{ Syok } \\
\hline $\mathrm{Ya}$ & $9(42,8)$ & $12(57,2)$ & 0,000 & $69(8,1-593,4)$ \\
\hline Tidak & $1(1,1)$ & $92(98,9)$ & & \\
\hline \multicolumn{5}{|c|}{ Distres napas } \\
\hline Ya & $7(41,2)$ & $10(58,8)$ & 0,000 & $21,5(4,9-98,4)$ \\
\hline Tidak & $3(3,2)$ & $94(96,8)$ & & \\
\hline \multicolumn{5}{|c|}{ Edema cerebri } \\
\hline Ya & $6(14,6)$ & $35(85,4)$ & 0,164 & $2,9(0,8-11,2)$ \\
\hline Tidak & $4(5,9)$ & $64(94,1)$ & & \\
\hline \multicolumn{5}{|c|}{ Status epileptikus } \\
\hline Ya & $7(21,2)$ & $26(78,8)$ & 0,006 & $6,9(1,7-28,7)$ \\
\hline Tidak & $3(3,8)$ & $77(96,2)$ & & \\
\hline \multicolumn{5}{|l|}{ Koma } \\
\hline Ya & $8(19,0)$ & $34(81,0)$ & 0,005 & $8,1(1,6-40,3)$ \\
\hline Tidak & $2(2,8)$ & $69(97,2)$ & & \\
\hline \multicolumn{5}{|c|}{ Lekositosis } \\
\hline Ya & $7(9,6)$ & $66(90,4)$ & 0,568 & $1,2(0,3-4,8)$ \\
\hline Tidak & $3(8,3)$ & $33(91,7)$ & & \\
\hline \multicolumn{5}{|c|}{ Leukosit CSS $\geq 100 \mathrm{sel} / \mathrm{mm}^{3}$} \\
\hline Ya & $0(0)$ & $19(100)$ & 0,036 & $1,1(1,0-1,2)$ \\
\hline Tidak & $6(8,5)$ & $65(91,5)$ & & \\
\hline \multicolumn{5}{|c|}{ Glukosa CSS $<40$} \\
\hline Ya & $0(0)$ & $11(100)$ & 0,446 & $1,1(1,0-1,2)$ \\
\hline Tidak & $6(7,6)$ & $73(92,4)$ & & \\
\hline \multicolumn{5}{|c|}{ Protein CSS $\geq 100$} \\
\hline Ya & $0(0)$ & $22(100)$ & 0,330 & $1,1(1,0-1,2)$ \\
\hline Tidak & $6(8,8)$ & $62(91,2)$ & & \\
\hline \multicolumn{5}{|c|}{ Pemberian antibiotik $>6$ jam } \\
\hline Ya & $3(7,7)$ & $36(92,3)$ & 0,480 & $0,7(0,18-3,0)$ \\
\hline Tidak & $7(10,1)$ & $62(89,9)$ & & \\
\hline \multicolumn{5}{|c|}{ Diagnosis kerja meningitis $>24$ jam } \\
\hline Ya & $1(20,0)$ & $5(80,0)$ & 0,341 & $2,2(0,2-20,9)$ \\
\hline Tidak & $9(8,3)$ & $99(91,7)$ & & \\
\hline
\end{tabular}

pasien meningitis bakterialis, hipertensi merupakan salah satu tanda peningkatan TIK ataupun Chusing syndrome yang harus segera ditangani. ${ }^{6,8}$

Terdapat penolakan terhadap tindakan pungsi lumbal oleh orangtua, sebagian besar tidak menuliskan alasan penolakan di formulir penolakan tindakan medis. Tiga orang menyatakan takut komplikasi akibat tindakan pungsi lumbal. Ketakutan orangtua terhadap komplikasi pungsi lumbal seperti paralisis, perdarahan atau nyeri merupakan alasan terbanyak penolakan pungsi lumbal. Alasan tersering lainnya, orangtua merasa tidak ada manfaat dari tindakan pungsi lumbal. ${ }^{10}$ Tidak ada perbedaan di antara tingkat pendidikan orangtua (sarjana dan bukan sarjana) dalam keputusan penolakan pungsi lumbal. Edukasi dan pemberian pemahaman yang baik mengenai pungsi lumbal kepada orangtua dapat mengurangi kecemasan dan ketakutan, serta meningkatkan penerimaan terhadap tindakan pungsi lumbal. ${ }^{10}$

Median lama waktu dilakukannya pungsi lumbal sejak pasien masuk adalah 4,5 jam (rata-rata 13,9 jam, rentang interkuartil 2,3-18,2 jam). Hasil 
tersebut serupa dengan hasil audit yang dilakukan oleh Stockdale $\mathrm{dkk}^{3}$ di Cambridge University Hospital dengan median 5,9 jam (rentang interkuartil 4,2-13,5 jam). Seharusnya, pungsi lumbal dilakukan dalam 4 jam sejak pasien masuk rumah sakit. ${ }^{6}$ Kemungkinan lamanya waktu tersebut dapat berhubungan dengan pemeriksaan funduskopi sebagai salah satu cara menentukan ada tidaknya kontra indikasi pungsi lumbal dan pemeriksaan tersebut dilakukan pada semua pasien. Seharusnya, pemeriksaan tersebut tidak diperlukan pada bayi dengan ubun-ubun masih terbuka dan ubun-ubun tidak tegang dan tidak membonjol. Pemeriksaan funduskopi dilakukan bersama sama dengan ophtamologist, pungsi lumbal lebih cepat dilakukan pada kelompok dengan konsultasi kepada ophtalmologist langsung dilakukan di UGD (rata-rata 12,2 jam, median 3,2jam) dibandingkan konsultasi dilakukan ketika di bangsal (rata-rata 14,9jam, median 6,9 jam.

Pemeriksaan funduskopi untuk menentukan ada tidaknya edema papil dilakukan bersama-sama dengan ophtalmologist. Kondisi ini serupa dengan penelitian Murad dkk ${ }^{11}$ yang menunjukkan bahwa pemeriksaan funduskopi sudah banyak dilupakan oleh dokter dan residen ilmu kesehatan anak. Pada penelitian di Israel tersebut ditemukan bahwa dari seluruh residen ilmu kesehatan anak yang diteliti, semuanya tidak mampu melakukan pemeriksaan funduskopi. ${ }^{11}$ Pelatihan pemeriksaan funduskopi berhasil meningkatkan kemampuan pemeriksaan funduskopi oleh residen ilmu kesehatan anak. ${ }^{11}$ Pelatihan serupa perlu dilakukan di RSUP Dr. Sardjito dan rumah sakit perlu menyediakan alat ophtalmoskop di UGD dan di bangsal anak.

Pengecatan gram untuk identifikasi bakteri patogen dilakukan hanya pada 47 dari 90 pasien. Pemeriksaan ini sering dilupakan klinisi atau pun petugas laboratorium, padahal pemeriksaan ini penting karena pengecatan gram dapat memberikan informasi awal mengenai kemungkinan bakteri penyebab pada 60\%-90\% meningitis bakterialis di komunitas. Pemeriksaan ini murah, mudah, cepat dan memiliki spesifitas tinggi. ${ }^{12}$ Sensitifitas pengecatan gram berkisar antara 60\%-90\% dan spesifisitas mendekati 100\%. ${ }^{13}$

Median lama waktu pemberian antibiotik sejak pasien masuk adalah 5 jam (rata-rata 6,9 jam, RIK 2,8-7,3 jam). Hasil tersebut lebih lama dibandingkan dengan hasil audit yang dilakukan Stockdale dkk, ${ }^{2}$ median 1,3 jam (RIK 0,4-3,55 jam). Seharusnya, antibiotik diberikan paling lama 6 jam sejak pasien masuk rumah sakit. ${ }^{6}$ Hanya $62 / 114$ pasien yang mendapatkan antibiotik dosis intrakranial dalam waktu 6 jam sejak pasien masuk. Namun, tidak ditemukan perbedaan angka kematian pada pasien yang mendapatkan antibiotik kurang dari 6 jam dibandingkan dengan pasien yang mendapatkan antibiotik lebih dari 6 jam. Hal tersebut karena pemberian antibiotik segera dilakukan pada pasien yang datang dengan keadaan umum buruk, yaitu terdapat kondisi syok, status epileptikus, distress napas ataupun koma. Dibandingkan dengan pasien dengan kondisi umum baik saat datang, antibiotik lebih cepat diberikan pada pasien dengan kondisi umum buruk, rata-rata 3,5 $\pm 2,2$ jam.

Walaupun demikian, pemberian antibiotik segera perlu dilakukan berdasarkan bukti dari beberapa penelitian pada populasi orang dewasa, ditunjukkan bahwa pemberian antibiotik seawal mungkin berhubungan dengan menurunnya angka kematian. Analisis multivariat terhadap 156 pasien dengan pneumokokal meningitis di 56 ruang rawat intensif di Perancis ditunjukkan bahwa keterlambatan pemberian antibiotik lebih dari 3 jam dari sejak saat masuk berhubungan dengan kematian. ${ }^{14}$ Hasil serupa juga diperoleh pada penelitian di Kanada yang menunjukkan bahwa keterlambatan pemberian antibiotik lebih dari 6 jam dari saat masuk rumah sakit berhubungan dengan mortalitas. ${ }^{15}$

Dari 104 pasien yang hidup, 63/104 (60,6\%) pasien kembali melakukan pemeriksaan di RSUP Dr. Sardjito, $11(10,6 \%)$ pasien menyatakan pemeriksaan pasca meningitis ke rumah sakit asal rujukan atau ke praktek dokter spesialis anak dan $30(28,8 \%)$ pasien tidak dapat dihubungi dan tidak ada data kunjungan ulang pasca rawat inap. Tes pendengaran dengan BERA dilakukan pada 26/63 pasien yang hidup, 1 pasien menolak pemeriksaan BERA karena faktor biaya, dan 37 (58,7\%) tidak ada penjelasan mengenai tidak dilakukannya pemeriksaan BERA. Hasil tersebut sama dengan hasil audit di Inggris yang dilakukan oleh Shield $\mathrm{dkk}^{16}$ terhadap anak yang dirawat dengan meningitis di Royal Belfast hospital. Pada penelitian tersebut, pemeriksaan BERA atau audiometri hanya dilakukan pada 16/32 (50\%) pasien pasca meningitis. Angka pemeriksaan BERA yang rendah pasca meningitis bakterialis kemungkinan disebabkan oleh pemeriksaan tidak langsung dilakukan ketika pasien masih dirawat sehingga ketaatan pasien rendah. Pemeriksaan BERA yang langsung dilakukan pada pasien meningitis 
menjelang pasien dipulangkan dapat meningkatkan ketaatan pasien, angka pemeriksaan BERA meningkat menjadi 86\% jika dibandingkan dengan pemeriksaan saat kunjungan ulang.

\section{Kesimpulan}

Belum semua kasus tata laksana meningitis bakterialis pada anak di RSUP Dr. Sardjito sesuai dengan pedoman SPM RSUP Dr. Sardjito 2005 dan PPM IDAI 2010. Rekomendasi dari audit ini adalah perlu diadakannya seminar atau workshop mengenai tata laksana meningitis bakterialis dan pelatihan pemeriksaan funduskopi.

\section{Daftar pustaka}

1. Rogier CJ, Furth AM, Wassenar M, Gernke R, Terwee CB. Predicting sequelae and death after bacterial meningitis in childhood: a systematic review of prognosis studies. BMC Infect Dis 2010;10:232-56.

2. WHO. Recommended Standards for Surveillance of Selected Vaccine-Preventable Diseases. WHODepartment of Vaccines and Biologicals, Geneva, 2003.

3. Stockdale AJ, Weekes MP, Aliyu SH. An audit of acute bacterial meningitis in a large teaching hospital 2005-10. Q J Med 2011;104:1055-1063.

4. Kemenkes RI. Keputusan Menteri Kesehatan Republik Indonesia Nomor 496/MENKES/SK/IV/2005 tentang Pedoman Audit Medis di Rumah Sakit. Kemenkes RI, 2005.

5. Andrew C, Greenall J, Dau Ding DC. UK Junior Doctors' Experience of Clinical Audit in the Foundation Programme. BJMP 2009;2:42-5.

6. National Institute for Health and Clinical Excellence
(NICE). NICE Clinical Guideline: Bacterial meningitis and meningococcal septicaemia in children. London: Royal College of Paediatrics and Child Health, 2010.

7. Chávez-Bueno S, McCracken GH Jr. Bacterial meningitis in children. Pediatr Clin North Am 2005;52:795.

8. Nudelman Y, Tunkel AR. Bacterial meningitis epidemiology, pathogenesis and management update. Drugs 2009;69:2577-96.

9. Mann K, Jackson MA. Meningitis. Pediatrics in Review 2007;29;417.

10. Hassib N, Ghatasheh G, Hassani NA, Reyami LA, Khan Q. Why Do Some Parents Refuse Consent for Lumbar Puncture on Their Child? A Qualitative Study. Hospital Pediatrics 2012;2:93.

11. Morad Y, Barkana Y, Avni I, Kozer E. Fundus anomalies: what the pediatrician's eye can't see. Int J Quality in Health Care 2004;16:363-5.

12. Tunkel AR, Hartman BJ, Kaplan SL. Practice guidelines for the management of bacterial meningitis. Clin Infect Dis 2004;39:1267.

13. Jerrard, D.A., Hanna, J.R., Schindelheim, G.L. Cerebrospinal fluid: Clinical Laboratory in Emergency Medicine. J Emerg Med 2001;21:171-8.

14. Auburtin M, Wolff M, Charpentier J, Varon E, Le Tulzo Y, Mohammedi I, dkk. Detrimental role of delayed antibiotic administration and penicillin-nonsusceptible strains in adult intensive care unit patients with pneumococcal meningitis: the PNEUMOREA prospective multicenter study. Crit Care Med 2006;34:2758-65.

15. Proulx N, Fre'chette D, Toye B, Chan J, Kravcik S. Delays in the administration of antibiotics are associated with mortality from adult acute bacterial meningitis. QJM 2005;98:291-8.

16. Shields M, Adams D, Beresford P. Managing meningitis in children: audit of notifications, rifampicin chemoprophylaxis, and audiological. Qual Health Care 2009;4:269-72. 